\title{
Kırsal turizm türlerinin belirlenmesinde bir araç: Ekosistem hizmetleri yaklaşımı
}

\author{
E. Seda Arslan Muhacir ${ }^{a, *}$, Ilkden Tazebay ${ }^{\text {b }}$
}

\begin{abstract}
Özet: Ankara-Haymana İlçesi örneğinde gerçekleștirilen bu çalıșmada ekosistem hizmetleri kırsal turizm türleri ile birlikte ele alınmışıır. Bu çalışmada amaçlanan ekosistem hizmetlerinin tanımlanması ve önceliklendirilmesi ile çalışma alanında ekosistem hizmetlerine dayalı en uygun kırsal turizm türünün belirlenmesidir. Bu amaçla analitik hiyerarşi süreci (AHS) ve Fuzzy set tekniklerinin birleşiminden oluşan bir model kullanılmıştır. Belirlenen ekosistem hizmetleri (gıda, tatlı su, biyokimyasal ve tıbbi ürünler, biyolojik hammadde, zararlı kontrolü, doğal afet kontrolü, polenleme, erozyon kontrolü, estetik değerler, rekreasyon ve eko turizm, bilgi sistemi, eğitim değeri) ile kırsal turizm türleri (tarımsal, termal ve kültürel turizm) ilişkilendirilerek ekosistem hizmetleri kapsamında en uygun kırsal turizm türü olarak termal turizm belirlenmiştir.

Anahtar kelimeler: Ekosistem hizmetleri, Kırsal turizm, Analitik hiyerarşi süreci, Fuzzy set, Haymana
\end{abstract}

\section{A tool in determination of rural tourism alternatives: The ecosystem services approach}

\begin{abstract}
This study is conducted in Ankara-Haymana County and based on linking ecosystem service benefits with rural tourism types. It aims to identify and prioritize ecosystem services and propose the suitable rural tourism type for the area by means of associating the benefits of these services with rural tourism types. For this purpose, the combination of Analytic Hierarchy Process (AHP) model and Fuzzy set technique is used. Selected ecosystem services -food, fresh water, biochemical natural medicines and pharmaceuticals, biological materials, pest regulation, natural hazard regulation, pollination, erosion regulation, aesthetic values, recreation and ecotourism, knowledge systems and educational values are associated with selected rural tourism options -agricultural, thermal and cultural tourism. Based on the findings, "thermal tourism" has been proposed as the most suitable tourism type for the study area under ecosystem services based decision support tools.

Keywords: Ecosystem services, Rural tourism, Analytic hierarchy process, Fuzzy set, Haymana
\end{abstract}

\section{Giris}

Geleneksel turizm anlayışında yaşanan değişimimler ve yeni arayışlar sonucu önem kazanan kırsal turizm, kırsal alanlarda gerçekleştirilen fiziksel, kültürel ve sosyal aktiviteler ile ilişkilidir. Kırsal alanlardaki ekolojik ve kültürel değerler potansiyeli üzerine kurgulanan kırsal turizm aktiviteleri rasyonel bir biçimde planlanmadıkları takdirde doğal ve kültürel değerlerin yanı sıra peyzajın özgün özelliklerinin kaybına neden olabileceğinden sürdürülebilirliği tehdit etmektedir. Ülkemizdeki kırsal alanların sürdürülebilir anlayışa uygun olarak kullanılması çevrenin kalitesine, çevrenin tüm kaynaklarından korumakullanma dengesinin sağlanarak yararlanılmas ına ve turisti o yeri ziyaret etmeye motive eden tüm değerlerin devamlı bir süreç halinde korunmasına bağlıdır (Soykan, 2003). Bu kapsamda gerçekleştirilmesi düşünülen kırsal turizm faaliyetleri için ekosistem hizmetlerine dayalı planlama yaklaşımları oldukça önemlidir. Doğal kaynakların sürdürülebilir kullanımını destekleyen bu yaklaşımların kırsal turizm aktivitelerinin planlanmasi sürecinde benimsenmesi kırsal peyzajın sunduğu doğal işlevler üzerindeki olumsuz baskıyı azaltacaktır.

$\mathrm{Bu}$ doğrultuda, kırsal turizm aktivitelerinin gerçekleştirildiği alanların ekos is tem hizmetleri kapsamında değerlendirilmesi, potansiyellerinin belirlenmesi ve her alanın potansiyeline yönelik aktivitelerin planlanması, bu alanların sürdürülebilirliğinin sağlanmasına destek olacaktır. Ayrıca ekosistem hizmetlerine dayalı planlama, yönetim ve tasarım çalıșmalarında yenilikçi araçların uygulanması ekolojik süreçlerin sürdürülebilirliğini destekleyici bir rol üstlenecektir. Ekosistem hizmetlerine dayalı planlama yaklaşımlarıyla, insanın doğal kaynaklardan sağladığ 1 ürün ve faydalar daha gerçekçi olarak belirlenebilir, ekosistem hizmetlerinin mekânsal dağılımları ve birbirleriyle ilişkileri irdelenerek koruma-kullanma dengesini sağlayan sürdürülebilir mekânsal yönetim yaklaşımları gerçekleştirilebilir (Tezer vd., 2015).

Çalışmanın konusu, kırsal turizm ve ekosistem hizmetleri ilişkisini kurmak ve bu doğrultuda ekosistem hizmetleri kapsamında en uygun kırsal turizm türünü belirlemektir. $\mathrm{Bu}$ çerçevede ekosistem hizmetleri ve kırsal turizm türleri AHS yoluyla ilişkilendirilerek her bir kırsal turizm türünün çalışma alanındaki ekosistem hizmetleri bağlamında uygunluk derecesi belirlenmiştir.

\subsection{Kavramsal çerçeve}

Dünya Kaynakları Enstitüsü tarafindan 2005 yılında yayınlanan Binyıl Ekosistem Değerlendirmesi (MEA)

\footnotetext{
a Artvin Çoruh Üniversitesi Orman Fakültesi Peyzaj Mimarlı̆ı̆ Bölümü, Artvin

${ }^{\mathrm{b}}$ Ankara Üniversitesi Ziraat Fakültesi Peyzaj Mimarlığı Bölümü, Ankara

@ ${ }^{*}$ Corresponding author (İletişism yazarı): esarslan@ @art vin.edu.tr

$\checkmark$ Received (Geliş tarihi): 11.05.2016, Accepted(Kabul tarihi): 14.11.2016
}

Citation (Atıf): Arslan Muhacir,E.S., Tazebay, İ., 2017. Kırsal turizm türlerinin belirlenmesinde bir araç: Ekosistem hizmetleri yaklașımı. Turkish Journal of Forestry, 18(1): 74-81. DOI: $\underline{10.18182 / \mathrm{tif} .308633}$ 
raporunda tanımlandı̆̆ ekosistemlerden elde edilen faydaları ifade etmektedir. Ekosistem hizmetleri kavramı daha çok ekosistem süreçleri ve biyoçeşitlilik konuları ile ilişkilendirilerek ele alınmış, yorumlanmış ve farklı şekillerde tanımlanmıştır. Ekosistem hizmetleri temel olarak "ins an hayatının sürdürülebilmesi ve insan refahının sağlanabilmesi için ekosistemlerin sunduğu durumlar, süreçler, işlevler, faydalar ve ürünlerin tümü” olarak da tanımlanmaktadır (Albayrak, 2012). Ekosistemler pek çoğu toplumun sağlığ 1 ve refahı için hayati önem taşıyan sayısız hizmet üretmektedirler (Comino vd., 2014). Ekosistemlerden elde edilen faydalar gida, su, temiz hava, tıbbi hammadde, rekreasyon ve kültürel değerler gibi pek çok farklı şekilde ortaya çıkmakta, doğanın bu faydaları yeryüzündeki diğer canlılar gibi insanlar için de hayati önem taşımaktadır (Albayrak, 2012). Ekosistem hizmetleri konusunda literatürde yer alan çok sayıda çalışma ekosistemhizmetlerini ekolojik, ekonomik ve sosyal açıdan ele alan, tanımlayan ve sınıflandıran çalışmalardır (Costanza vd., 1997, Boyd ve Banzhaf, 2007, Daily vd., 2009, De Groot vd., 2010, Hermann vd., 2011, Logsdon, 2011, Kubiszewski ve Costanza, 2012,). Son y1llarda bilim dünyasinda ekosis tem hizmetleri konusuna verilen önem ve artan farkındalık sonucunda ekos is tem hizmeti yaklaşımını geliştirmeye yönelik çalışmalar yayınlanmıştır. Ekosistem hizmetlerini tanımlama ve sinıflandırma konularında yapılan bu çalışmalarda MEA (2005)'da yer alan tanımlama ve sinıflandırmanın esas alındığ 1 ve bu doğrultuda değerlendirmeler yapıldığı görülmektedir (Costanza vd., 1997, Boyd ve Banzhaf, 2007, Daily vd., 2009, Albayrak, 2012). MEA (2005)'da ekosistem hizmetleri dört başlik altında sınıflandırılmıştır. Bunlar tedarikçi, düzenleyici, kültürel ve destekleyici hizmetlerdir. Bu kapsamda bu çalışmada da MEA (2005)'de yer alan sinıflandırma ve tanımlamalardan yararlanılmış, MEA (2005) raporunda yer aldığ1 biçimiyle destekleyici hizmetlerin doğrudan insan faaliyetlerini etkilememesi ya da değişmesine sebep olmaması nedeniyle değerlendirme kapsamına alınmamıştır (Çizelge 1).

Kirsal turizm, geleneksel kitle turizmine alternatif olarak ortaya çıkan, kırsal alanların sosyo-ekonomik olarak canlanmasıve turizme bağlı sanayi sektörünün gelişmesine katk1 sağlayan (Hernandez vd., 2016), yerel halk tarafindan yerel kültür ve peyzaja bağlı olarak şekillendirilen, yönetilen ve geliştirilen bir turizm türü olarak tanımlanmaktadır (Aleksieva ve Stamov, 2005; Barkauskas vd., 2015). Bu kapsamda yapılan çalışmalarda; tarımsal turizm, yayla turizmi, avcılık, balıkçlık kültürel turizm, termal turizm, kuş gözlemciliği, macera tatilleri, kano ve rafting, dağcılık gibi turizm türleri kırsal turizm bağlamında değerlendirilmektedir.

$\mathrm{Bu}$ çalş̧mada, çalışma alanının kültürel, termal ve tarımsal özellikleri göz önünde bulundurularak potansiyel turizm türleri olarak "kültürel", "termal" ve "tarımsal" turizm türleri değerlendirmeye alınmıştır.

\section{Materyal ve yöntem}

Çalışma alanı olarak belirlenen Haymana İlçesi, nüfus yoğunluğunun düşük, tarımın ekonomik faaliyetlerin temelini oluşturduğu Ankara İlinin güney ve güneydoğu kesimlerini kapsayan bölgede yer almaktadır (Şekil 1). Bölge genelinde yüks ek oranda nüfus kaybı yaşanmaktadır. İlçenin, 2008-2015 yılları arasında nüfus değișim oranı \% 22 ve 2015 yılı nüfusu 31.176 kişidir (AKA, 2015).

Çizelge 1. Ekosistem hizmetleri s inıflandırması (MEA, 2005)

\begin{tabular}{|c|c|}
\hline $\begin{array}{l}\text { Ekosistem hizmetleri } \\
\text { ana grubu }\end{array}$ & Ekosistem hizmetleri \\
\hline Tedarikçi & $\begin{array}{l}\text { Gida, tatlı su, lifli ürünler, biyolojik hammadde, genetik kaynaklar, biyokimyasal ve tıbbi ürünler, dekoratif } \\
\text { kaynaklar }\end{array}$ \\
\hline Düzenleyici & $\begin{array}{l}\text { Hava kalitesi düzenleme, iklim düzenleme, su akışı kontrolü, erozyon kontrolü, su ve katı atık arıtma, salgın } \\
\text { hastalık önleme, doğal afet kontrolü, zararlı kontrolü, polenleme }\end{array}$ \\
\hline Kültürel & $\begin{array}{l}\text { Kültürel çeşitlilik, manevi ve etik değerler, eğitim değeri, bilgi sistemi, est etik değerler, ilham, mekan hissi, } \\
\text { sosyal değerler, kültürel miras değeri, rekreasyon ve ekoturizm }\end{array}$ \\
\hline
\end{tabular}

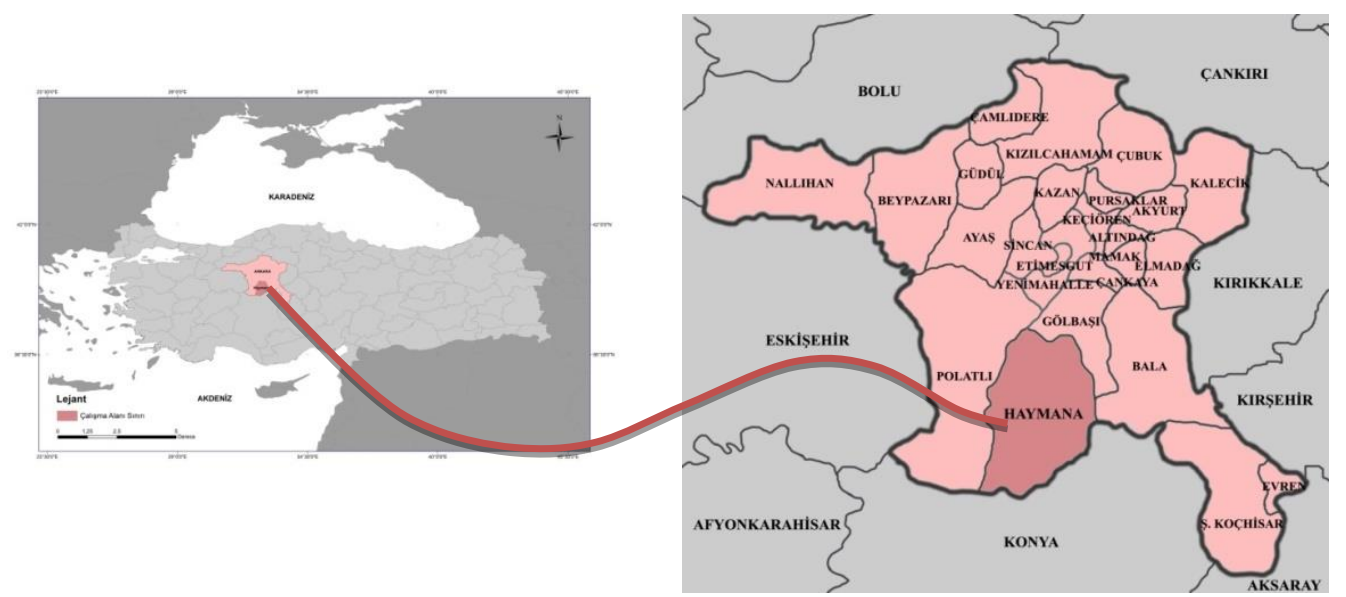

Şekil 1. Çalışma alanının konumu (Muhacir, 2014) 
İlçede tarım ve hayvancılık faaliyetleri yoğun olarak gerçekleştirilmekte olup, halkın büyük çoğunluğu geçimini bu yolla sağlamaktadır. Ayrıca mevcut termal kaynaklar termal turizm faaliyetleri için potansiyel oluşturmaktadır. Ulus lararası Şifalı Su Kaynakları Araştırma Merkezi'nin 30 ülkeyi kapsayan araştırmasına göre; Haymana Kaplıcaları nitelik bakımından dünyada ikinci sırada yer almaktadır (HB, 2016).

İlçe tarihte pek çok uygarlığa ev sahipliği yapması sebebiyle doğal, kültürel ve tarihi değerler açısından da zengin bir potansiyele sahiptir. Atatürk Evi ve Gavur Kalesi'nin yer aldığ Çalış Beldesi tarihi ve kültürel özellikler bakımından, Yenice ve Bumsuz beldeleri ve bunlara bağ lı köyler is e yaylaların ve diğ er alanlara nazaran farklı peyzaj görünümlerinin yer aldığ 1 doğal özellikler bakımından zengindir.

Çalışma kapsamında ekosistem hizmetleri ile kırsal turizm türleri, Fuzzy Set ve Analitik Hiyerarşi Süreci (AHS) teknikleri ile anket yoluyla ilişkilendirilerek değerlendirilmiştir. Arazi örtüsü haritası (1/100000 ölçekli CORINE 2006), arazi çalışmas inda elde edilen koordinatlar, Türkiye'deki Peyzaj Mimarlığ1 Bölümlerinde görev yapan ve çalışma alanı hakkında bilgi sahibi akademisyenlerden (15 kişi) oluşan uzman grup anketi sonuçları ana materyali oluşturmaktadır. Yüz yüze görüşme yoluyla gerçekleş tirilen anket 2 bölümden oluşmaktadır. $\mathrm{Bu}$ kapsamda katılımcılardan öncelikle önem derecesine göre ekosistem hizmetlerini (tedarikçi, düzenleyici, kültürel) birbirleri ile daha sonra ise her bir ekos is tem hizmet türünü çalışma alanı için belirlenmiş olan kırsal turizm türleri (tarımsal, termal, kültürel) ile karşılaştırmaları is tenmiştir.

Çalışma dört temel aşamadan oluşmaktadır:

Aşama 1: Ekolojik birimler ve potansiyel ekosistem hizmetlerinin belirlenmesi

Aşama 2: Öncelikli ekosistem hizmetleri ve kursal turizm türlerinin belirlenmesi

Aşama 3: Öncelik belirleme anketinin oluşturulması ve uygulanmas1

Aşama 4: Öncelik belirleme anketine ilişkin hesaplamaların yapılmas 1

AHS, 1970'lerin sonlarında Saaty tarafindan geliştirilmiştir (Saaty 1990). AHS'nin karar vericiler tarafindan tercih edilmesinin nedeni çok kriterli kararların alınmasında subjektif kriterleri dikkate alabilmesidir. Cok kriterli karar verme yaklaşımlarından olan AHS'de, nitel faktörler başlıca öneme sahiptir. Alternatiflerin ayrıntılı değerlendirmesinde nitelve sayıs al faktörleri birleştirebilen bir tekniktir. AHS çeşitli seviyelerde birbirinden bağımsız olan faktörlerin, içinde bulundukları hiyerarşik yapıda değerlendirilmesinde kullanılmaktadır (Anık, 2007).
Saaty (1990) tarafindan gelistirilen AHS'nin temel ilkeleri çerçevesinde şekillenen Fuzzy set tekniği, alan kullanım alternatiflerinin değerlendirilmesi ve seçiminde kullanılabilecek bir tekniktir. Fuzzy set fikri, AHS ile her faktörün göreceli değerinin alternatifler üzerindeki etkisine dayanmaktadır (Çizelge 2, Akpınar, 1995).

Analitik sıralama işlemlerine göre geliştirilmiş teknik, özellikleri bakımından bir grup olarak incelemeye alınacak kadar birbirine yakın ama eşit olmayan nesnelerin analiz edilmesine, irdelenmesine olanak tanır. Fuzzy set tekniği çoklu kriter tekniği olarak bilinir ve bu teknik incelenen her alternatifin toplam etkisinin hesaplanmasinı ve alternatiflerin seçimine etki eden her faktörün göreceli değerinin analizini kolaylaştırır. Fuzzy set analizinin sonucu, alternatiflere toplamları 1 olacak şekilde önem ağırlıkları ortaya koyarve ağırlığı en yüks ek olan alternatifi önem ağırlıkları düşük olanlara göre üstün kılar (Akpınar, 1995).

Tekniğin uygulanması sirasında AHS'nin temel değerlendirme ölçeğine göre iki elemanın karşı laş tırılmas ında birinin diğerine göre önemi konusunda değerlendirme yapacak bir uzman ya da uzman grubuna ihtiyaç duyulur. Matrislerin oluşturulmasının ardından her fuzzy set elemanının göreceli ağırlığ 1 , karşılıklı matris için temel özvektörün hesaplanmasıyla belirlenir (Akpınar, 1995).

\section{Bulgular}

\subsection{Ekolojik birimler ve potansiyel ekosistem hizmetleri}

CORINE 2006 arazi örtüsü haritasında kodların belirttiği arazi sınıfları üzerinden yapılan değerlendirmede, aşağıdaki arazi örtüsü tipleri elde edilmiştir (Çizelge 3).

Çizelge 3'de belirtildiği şekilde düzenlenen CORINE 2006 arazi örtüsü haritasına göl, gölet ve sulama kanalları da işlenmiştir.

Haymana İlçesi'nin arazi örtüsü haritasına göre ekolojik birimlere ayrilmasında, MEA (2005) raporundaki ekolojik birimler ve sağladığı ekosistem hizmetlerinden yararlanılmıştır. Bu kapsamda arazi örtüsü-ekolojik birimler iliş kisi kurulmuş ve harita üzerinde gösterilmiştir. Çalışma alanı arazi örtüsüne göre dört baş lık altında sınıflandırılarak ekolojik birimler tanımlanmıştır. Arazi örtüsü üzerinde yer alan kırsal yerleşim alanları ve yer altı kaynakları bir ekolojik birim olmamas1 sebebiyle tarim alanlan kapsamında değerlendirilmiştir. Ayrıca arazi örtüsü haritasında yer alan göl, gölet ve sulama kanalları da birleştirilerek ekolojik birim haritasında iç sular olarak ele alınmıştır. Buna göre ekolojik birimler haritasında yer verilen ekolojik birimler "tarım alanları", "meralar", "yanı doğal alanlar" ve "iç sular"dır (Şekil 2).

Çizelge 2. AHS temel değerlendirme ölçeği (Saaty, 1990)

\begin{tabular}{cll}
\hline Onem derecesi & Tanımı & Açılaması \\
\hline 1 & Eşit derecede önemli & 1.ve 2.etken eşit derecede önemli \\
3 & Zayıf derecede daha önemli & 1.etken 2.etkene göre biraz daha önemli \\
5 & Azımsanmayacak derecede daha önemli & 1.etken 2.etkene göre fazla önemli \\
7 & İspatlanmış derecede daha önemli & 1.etken 2.etkene göre çok fazla önemli \\
9 & Kesinlikle daha önemli & 1.etken 2.etkene göre aşırı derecede önemli \\
$2,4,6,8$ & Ara değerler & 1 ve 2.etken birbirineyakın değerlere sahip, ya da iki değer arasında uzlaşma var \\
\hline
\end{tabular}


Çizelge 3. Corine arazi örtüsü sınıflandırmas ına göre arazi örtüsü tipleri

\begin{tabular}{lcl}
\hline Corine arazi örtüsü sınıfı & Corine arazi kodu & Arazi örtüsütipi \\
\hline Maden çıkarım sahaları & 131 & Maden çıarım sahaları \\
Meralar & 231 & Meralar \\
Kesikli kırsal yapı & 1122 & Kırsal yerleşim alanları \\
\hline Doğal bitki örtüsü ile bulunan tarım alanları & 243 & \\
Sulanmayan ekilebilir alan & 2111 & \\
Sulanan alan & 2121 & Tarım alanları \\
Sulanmayan karışı tarım & 2421 & \\
Sürekli sulanan karışık tarım & 2422 & \\
\hline Doğal çayırlıklar & 321 & Yarı doğal alanlar \\
Bitki değişim alanları & 324 & \\
Seyrek bitki alanları & 333 & İç sular \\
\hline Bataklıklar & 411 & \\
Su kütleleri & 512 & \\
\hline
\end{tabular}

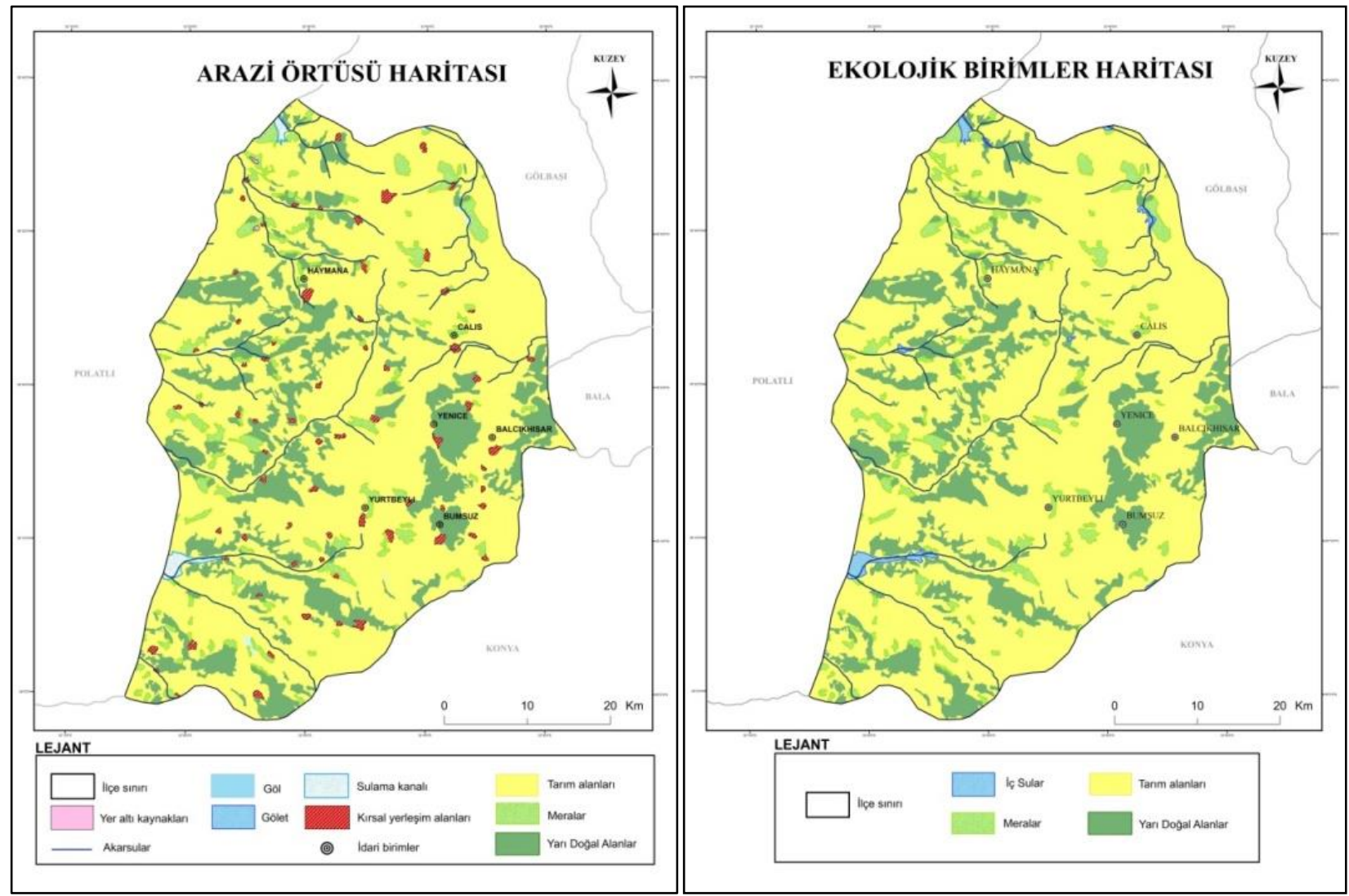

Şekil 2. Arazi örtüsü ve ekolojik birimler (Muhacir, 2014)

\section{2. Öncelikli ekosistem hizmetleri ve kırsal turizm türleri}

Çalışma alanındaki öncelikli ekosistem hizmetlerini belirlemek için MEA 2005 raporundaki potansiyel ekosistem hizmetleri ele alınmış ve çalışma alanındaki ekolojik birimlerin bu hizmetlerin hangileri tarafindan sağlandığg 1 Çizelge 4'de gösterilmiştir.

Çizelge 3'de gösterilen ve çalışma alanındaki ekolojik birimler tarafindan sağlanan ekosis tem hizmetleri aşağıdaki kriterlere göre değerlendirilerek öncelikli ekosistem hizmetleri belirlenmiştir. Kriterlerin belirlenmesinde Albayrak (2012) çalıșması ve çalıșma alanının sahip olduğu ekosistem hizmeti potansiyeli dikkate alınmıştır.

Kriter 1: Çalısma alanının tarımsal potansiyeli yüksek bir alan olmas 1

Kriter 2: Ekolojik hizmetlerin en az 2 ekolojikbirim tarafindan sağlanıyor olması
Kriter 3: Belirlenen hizmetlerin değerlendirilmesi ile ilgili yeterli verinin mevcut olmas 1

Kriter 4: Belirlenen hizmetlerin farklı ekosistem hizmet sınıflarını ifade etmesi (Tedarikçi, Düzenleyici, Kültürel gibi)

Kriter 5: Belirlenen hizmetlerin kursal turizm faaliyetlerini destekleyici özellikleri sağlıyor olmas 1

Buna göre her bir ES ana grubu kapsamında belirlenen öncelikli ekosistem hizmetleri aşağıdaki gibidir:

Tedarikçi: Gida, tatlı su, biyolojik hammadde, biyokimyasal ve tıbbi ürünler

Düzenleyici:Zararlı kontrolü, doğal afet kontrolü, polenleme, erozyon kontrolü

Kültürel: Estetik değerler, rekreasyon ve eko turizm, bilgi sis temi, eğitim değeri 
Çizelge 4. Ekolojik birimler tarafindan sağlanan potansiyel ekos istem hizmetleri (MEA, 2005)

\begin{tabular}{ll}
\hline Ekolojik birimler & Potansiyel ekosistem servisleri \\
\hline & Gida \\
& Tatlısu \\
& Lifloli ürünler hammadde \\
& Biyokimyasal ve tıbbi ürünler \\
& Zararlı kontrolü \\
& Polenleme \\
& Besin döngüsü \\
& Fotosentez \\
& Bilgi sistemi \\
& Estetik değerler \\
& Eğitim değeri \\
& Kültürel miras değeri \\
& Rekreasyon ve ekoturizm \\
\hline Gida alanları & Biyolojik hammadde \\
& Dekoratif kaynaklar \\
& Biyokimyasal ve tıbbi ürünler \\
& Su akışı kontrolü \\
& Erozyon kontrolü \\
& Zararlı kontrolü \\
& Doğal afet kontrolü \\
& Estetik değerler \\
& Mekan hissi \\
& Sosyal ilişkiler \\
& Manevi ve etik değerler \\
& Rekreasyon ve ekoturizm \\
\hline & \\
\hline Yarı doğal alanlar
\end{tabular}

Çalışma alanındaki potansiyel kırsal turizm türlerinin belirlenmesinde ise Türkiye Turizm Stratejisi 2023, Eylem Planı 2007-2013 (KTB, 2007) ve çalışma alanındaki turizm kaynakları dikkate alınmıştır. Kırsal turizm türlerinin belirlenmesinde;

- Türkiye Turizm Stratejisi 2023 ve Eylem Planı 20072013'de çalş̧ma alanın da içinde bulunduğu bölgenin Frigya Termal ve Kültür Turizmi Gelişim Bölgesi olarak ilan edilmesi,

- Çalışma alanında tarım faaliyetlerinin yoğun olarak yapilmas1,

- Çalışma alanının pek çok uygarlığa ait izler taşıması ve çalışma alanında kültürel yapıların yer alması dikkate alınmıştır.

$\mathrm{Bu}$ kapsamda aşağıdaki kırsal turizm türleri (KTT) belirlenmiştir.

- KTT1: Tarımsal Turizm

- KTT2: Termal Turizm

- KTT3: Kültürel Turizm

\section{3. Öncelik belirleme anketi}

Anket, kırsal turizm türlerinin önceliklerini belirlemek amacı ile uygulanmıştır. Bu amaçla, çalışma alanındaki öncelikli ekos is tem hizmetlerine iliş kin veriler, kırsal turizm türleri ile Fuzzy set tekniğine uygun olarak hiyerarşik şekilde gruplandırılmıştır (Şekil 3).

\begin{tabular}{ll}
\hline Ekolojik birimler & Potansiyel ekosistem servisleri \\
\hline & Gida \\
& Genetik kaynaklar \\
& Biyokimyasal ve tıbbi ürünler \\
& Su akışı kontrolü \\
& Erozyon kontrolü \\
& Polenleme \\
& Toprak formasyonu \\
& Besin döngüsü \\
Su döngüsü \\
Meralar & Fotosentez \\
& Bilgi sistemi \\
& Estetik değerler \\
& Eğitim değeri \\
& İlham \\
\hline & Gida \\
& Tatlı su \\
& Hava kalitesi düzenleme \\
& İklim düzenleme \\
& Su akışı kontrolü \\
& Salgin hastalı önleme \\
& Doğal afet kontrolü \\
& Besin döngüsü \\
& Estetik değerler \\
& Eğitim değeri \\
& Rekreasyon ve ekoturizm \\
& \\
\hline İç sular &
\end{tabular}

Şekil 3'deki hiyerarşik modele göre hazırlanan öncelik belirleme anketi belirlenen uzman gruba uygulanmıştır. Anket kapsamında uzmanlar tedarikçi, düzenleyici ve kültürel hizmetler ve belirlenen kırsal turizm alternatifleri dahil olmak üzere toplam 54 adet karşılaştırmalı soruya cevap vermiş lerdir.

Örneğin tedarikçi hizmetler için yapılan değerlendirmede;

- Ekosistem hizmetleri karşılaştırılmıştır.

- Tedarikçi hizmetler karşılaş tırılmıştır.

- Tedarikçi hizmetlerin her biri için kırsal turizm türleri karş 1laştırılmış tır.

- Tedarikçi hizmetlerin tümü için kırsal turizm türleri karşılaştırılmıştır.

Yukarıda tedarikçi hizmetler için izlenen sıralama, benzer şekilde düzenleyici ve kültürel hizmetler için de uygulanmıştır.

\section{4. Öncelik belirleme anketi hesaplamalart}

Ekosistem hizmetlerinin AHS kullanılarak değerlendirilmesinde öncelikle ekosistem hizmetleri karşılaştırılmıştır. Aşağıda, karşıllaştırılması yapılan tedarikçi (T), düzenleyici (D) ve kültürel hizmetlerden (K) her birinin bir ekosistem hizmet tipini ifade etmesi nedeniyle önemi eşit olarak kabul edilmiştir (Çizelge 5). 


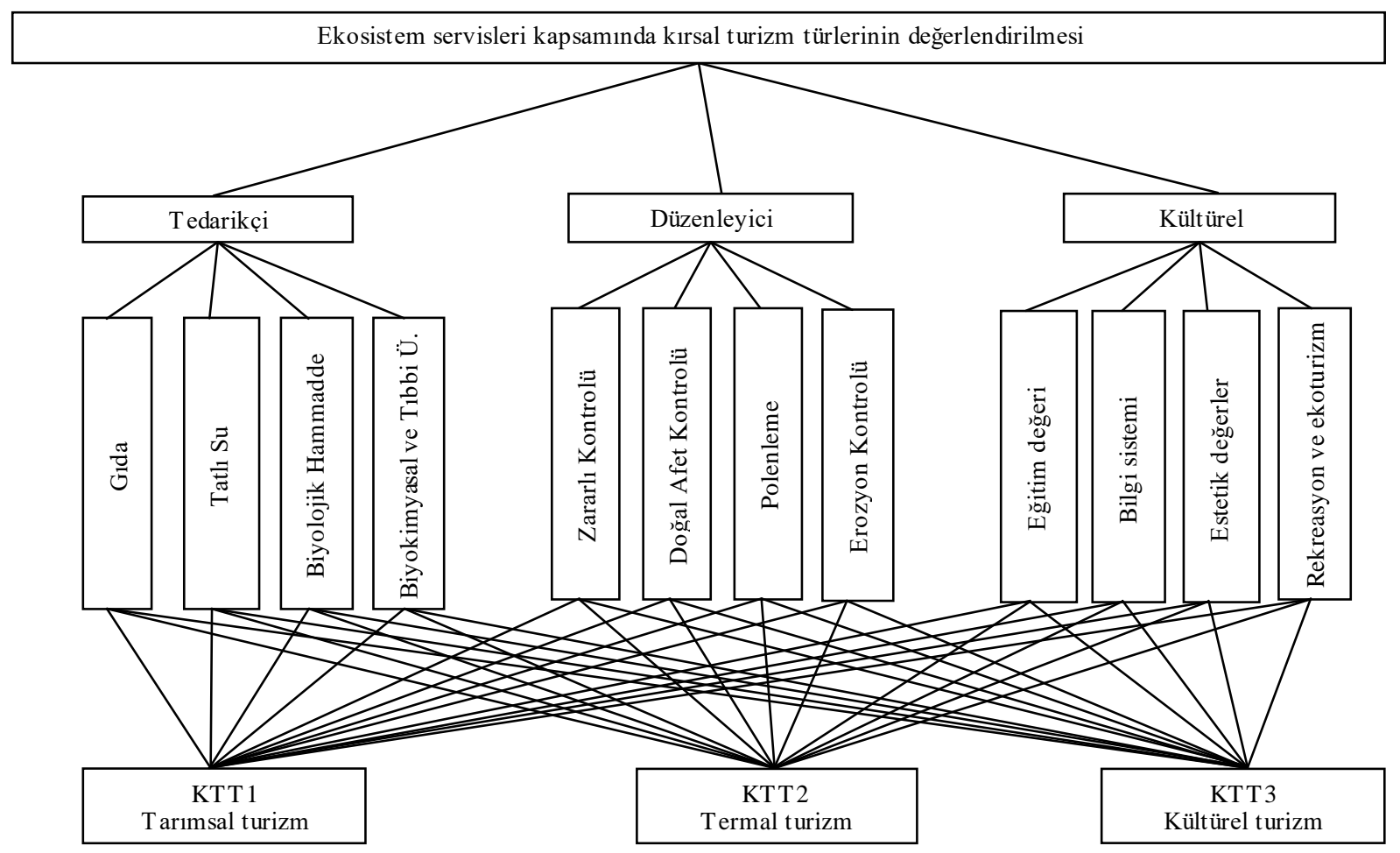

Şekil 3. Çalışma alanında kırsal turizm türleri ve değerlendirme faktörlerine ilişkin Fuzzy set modeli (Muhacir, 2014)

Çizelge 5.Ekos istemhizmetlerinin birbirilerine göre ağırlikları

\begin{tabular}{llll}
\hline & T & D & K \\
\hline Tedarikçi hizmetler & 1 & 1 & 1 \\
Düzenleyici hizmetler & 1 & 1 & 1 \\
Kültürel hizmetler & 1 & 1 & 1 \\
\hline
\end{tabular}

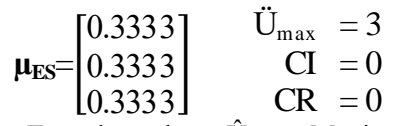

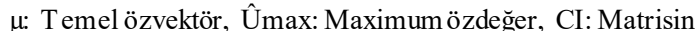
uyumluluğu, CR: Uyumluluk oranı

Her bir ekosistem hizmet tipinin eșit olarak kabul edilmesinin ardından tedarikçi, düzenleyici ve kültürel hizmetler karşılaştırılmıştır (Çizelge 6, 7 ve 8).

Tedarikçi hizmetlerden gıda (T1), tatlı su (T2), biyolojik hammadde (T3) ve biyokimyasal ve tıbbi ürünler (T4) birbirleri ile karşılaştırılmış ve aşağıdaki değerler elde edilmiștir. Buna göre, T1 satırı ile T2 sütununun kesiştirilmesinden T1'in T2'ye göre ağırlığ 14.6930 olarak bulunmaktadır.

Çizelge 6. Tedarikçihizmetlerin birbirlerine göre ağırlıkları

\begin{tabular}{ccccc}
\hline & T1 & T2 & T3 & T4 \\
\hline T1 & 1.0000 & 4.6930 & 2.4910 & 1.7750 \\
T2 & 0.2131 & 1.0000 & 1.1500 & 0.2190 \\
T3 & 0.4014 & 0.8696 & 1.0000 & 1.3340 \\
T4 & 0.5634 & 4.5662 & 0.7496 & 1.0000
\end{tabular}

T1:Gida, T2:Tatl1 su, T3: Biyolojik hammadde, T4:Biyokimyasal ve tıbbi ürünler

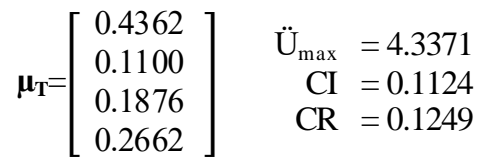

Tedarikçi hizmetlerin karşılaştırılmasının ardından, belirlenen her bir kırsal turizm türü de tedarikçi hizmetlerin tümüyle ayrı ayrı karşılaştırılarak uygunlukları belirlenmiştir. Tedarikçi hizmetlerin tümünün karşılaştırılması sonucu, hangi kırsal turizm türünün en uygun olduğu ortaya çıkmıştır. Aşağıda T1, T2, T3 ve T4 hizmetlerinin altında yazan değerler, her bir tedarikçi hizmetin kırsal turizm türleri ile karşılaştırılmasından elde edilen $\boldsymbol{\mu}$ değerleridir. $\mathrm{Bu}$ değerler yan yana yazılarak, tedarikçi hizmetlerin birbirleri ile karşılaştırılmasından edilen özvektör ile ayrı ayrı çarpılıp, karşılıklı toplanarak kırsal turizm türlerinin uygunluk değeri belirlenmiştir. Aynı işlemler düzenleyici ve kültürel hizmetler için de ayrı ayrı

\begin{tabular}{|c|c|c|c|c|c|}
\hline $\mathrm{T} 1$ & $\mathrm{~T} 2$ & T3 & $\mathrm{T} 4$ & Özvektör & Türler \\
\hline & 0.5113 & 0.1482 & $0.4099]$ & {$[0.4362$} & {$[0.3177$ (KTT1)] } \\
\hline & 0.3089 & 0.6418 & 0.3410 & $\begin{array}{l}0.1100 \\
0.1876\end{array}$ & $=0.4800($ KTT2) \\
\hline 760 & 0.1798 & 0.2101 & $0.2491]$ & $\begin{array}{l}0.1866 \\
0.262\end{array}$ & {$[0.2023$ (KTT3) $]$} \\
\hline
\end{tabular}
tekrarlanmıştır.

Tedarikçi hizmetlerin tümü dikkate alındığında uygunluk siralamasi; 0,4800 değeri ile termal turizm (KTT2) ve 0,3177 değeri ile tarımsal turizm (KTT1)'dir.

Çizelge 7. Düzenleyicihizmetlerin birbirlerine göre ağırlıkları

\begin{tabular}{lcccc}
\hline & D1 & D2 & D3 & D4 \\
\hline D1 & 1.0000 & 3.8360 & 3.5360 & 3.3740 \\
D2 & 0.2607 & 1.0000 & 1.8470 & 2.6870 \\
D3 & 0.2828 & 0.5414 & 1.0000 & 2.3890 \\
D4 & 0.2964 & 0.3722 & 0.4186 & 1.0000 \\
\hline
\end{tabular}

D1 :Zararlı kontrolü, D2:Doğal afet kontrolü, D3: Polenleme,

D4:Erozyon kontrolü 


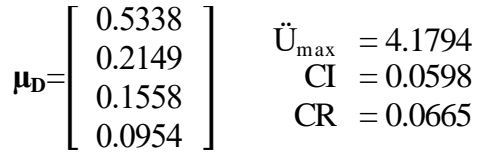

$\begin{array}{ccccc}\text { D1 } & \text { D2 } & \text { D3 } & \text { D4 Özvektör } & \text { Türler } \\ {\left[\begin{array}{cccc}0.2448 & 0.4836 & 0.1518 & 0.3727 \\ 0.4801 & 0.3678 & 0.5788 & 0.4346 \\ 0.2751 & 0.1486 & 0.2694 & 0.1927\end{array}\right] *\left[\begin{array}{l}0.5338 \\ 0.2149 \\ 0.1558 \\ 0.0954\end{array}\right]=\left[\begin{array}{c}0.2939 \text { (KTT1) } \\ \mathbf{0 . 4 6 7 0 ( K T T 2 )} \\ 0.2391 \text { (KTT3) }\end{array}\right]}\end{array}$

Düzenleyici hizmetlerin tümü dikkate alındığında uygunluk suralamas1; 0,4670 değeri ile termal turizm (KTT2) ve 0,2939 değeri ile tarımsal turizm (KTT1) dir.

Çizelge 8. Kültürelhizmetlerin birbirlerine göre ağırlıkları

\begin{tabular}{ccccc}
\hline & $\mathrm{K} 1$ & $\mathrm{~K} 2$ & $\mathrm{~K} 3$ & $\mathrm{~K} 4$ \\
\hline $\mathrm{K} 1$ & 1.0000 & 3.9280 & 3.1340 & 3.7960 \\
$\mathrm{~K} 2$ & 0.2546 & 1.0000 & 2.7160 & 4.3130 \\
$\mathrm{~K} 3$ & 0.3191 & 0.3682 & 1.0000 & 2.9840 \\
$\mathrm{~K} 4$ & 0.2634 & 0.2319 & 0.3351 & 1.0000 \\
\hline
\end{tabular}

K1:Eğitim değeri, K2:Bilgi sistemi, K3:Estetik değerler, K4:Rekreasyon ve eko turizm

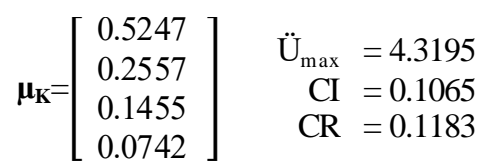

\begin{tabular}{|c|c|c|c|c|c|}
\hline K1 & $\mathrm{K} 2$ & K3 & K4 & Özvektör & Türler \\
\hline$[0.3955$ & 0.4957 & 0.3931 & $0.6414]$ & & {$[0.4390$ (KTT 1)] } \\
\hline 0.5091 & 0.4145 & 0.5224 & 0.2814 & $\begin{array}{l}0.2557 \\
0.1455\end{array}$ & $0.4700\left(K_{T T 2}\right)$ \\
\hline 0.0954 & 0.0898 & 0.0845 & $0.0772]$ & {$\left[\begin{array}{l}0.1455 \\
0.0742\end{array}\right]$} & {$[0.0910$ (KTT3) } \\
\hline
\end{tabular}

Kültürel hizmetlerin tümü dikkate alındığında uygunluk sıralamas1; 0,4700 değeri ile termal turizm (KTT2) ve 0,4390 değeri ile tarımsal turizm (KTT1) dir.

Ekosistem hizmetlerinin tümünün karşılaştırılması sonucundaise hangi kırsal turizm türünün çalışma alanı için en uygun olduğu ortaya çıkmıştır.

$$
\begin{array}{ccc}
\mathrm{T} & \mathrm{D} & \mathrm{K} \\
{\left[\begin{array}{lll}
0.3177 & 0.2939 & 0.4390 \\
0.4800 & 0.4670 & 0.4700 \\
0.2023 & 0.2391 & 0.0910
\end{array}\right]} & \text { Özvektör } & \text { Türler } \\
{\left[\begin{array}{l}
0.3333 \\
0.3333 \\
0.3333
\end{array}\right]} & =\left[\begin{array}{c}
0.3500(\text { KTT1) } \\
\mathbf{0 . 4 7 2 1}(\text { KTT2) } \\
0.1773 \text { (KTT3) }
\end{array}\right]
\end{array}
$$

T: T edarikçi hizmetler, D: Düzenleyici hizmetler, K: Kültürel hizmetler KTT 1: Tarmsal Turizm, KTT2: Termal Turizm, KTT3: Kültürel Turizm

Ekosistem hizmetlerinin tümü dikkate alındığında en uygun kırsal turizm türü, 0,4721 değeri ile termal turizm (KTT2)'dir. Termal turizmi 0,3500 değeri ile tarımsal turizm (KTT1) izlemektedir. Oluşturulan matrislerdeki katsayıların tutarlı oluşu sonuçların güvenirliğini kanitlamaktadir.

\section{Değerlendirme ve sonuç}

Çalışma kapsamında kırsal turizm ile ekosistem hizmetleri ilişkisi kurularak, bu ilişkiye yönelik öneri bir model geliştirilmiş ve çalışma alanı için belirlenen kırsal turizm türleri, ekosistem hizmetleri kapsaminda değerlendirilerek en uygun kırsal turizm türü belirlenmiştir.

Termal turizmin en uygun tür olarak belirlenmesi Haymana İlçesi'nde ekosistem hizmetlerinden elde edilen faydaların dolaylı faydalar olduğunu göstermektedir. Öyle ki AHS ile öncelik belirleme anket çalışması sonuçları incelendiğinde rekreasyon ve ekoturizm hizmeti için tarımsal turizm uygun tür olarak belirlenirken, gıda hizmeti içinse termal turizmin en uygun tür olduğu görülmektedir.

Ayrıca tedarikçi, düzenleyici ve kültürel hizmetlerin her biri ayrı ayrı kırsal turizm türleri ile karşılaştırıldığında elde edilen sonuçlar, gerçekleştirilecek olan kırsal turizm faaliyetlerinin her biri için hangi hizmetler üzerinde baskı kurulacağını, ya da hangi hizmetlerin en çok bu faaliyetleri destekleyeceği konusunda bilgi vermektedir. Örneğin, termal turizm faaliyetlerini gida, biyolojik hammadde, zararlı kontrolü, polenleme, erozyon kontrolü, eğitim değeri ve estetik değer hizmetleri desteklerken, tarımsal turizm faaliyetlerini tatlı su, biyokimyasal ve tıbbi ürünler, doğal afet kontrolü, bilgi sistemi ve rekreasyon ve ekoturizm hizmetleri desteklemektedir. Her bir ekolojik birimin birden fazla ekosistem hizmeti üretme potansiyeli olduğu gerçeğiyle, çalışma alanında ekos is tem hizmetlerinin büyük çoğunluğunun her bir ekolojik birim tarafindan üretildiği görülmektedir. Çalışma alanının nüfus yoğunluğu olmayan kırsal bir alan olmas1 sebebiyle olas1 termal ve tarımsal turizm faaliyetleri kapsamında ekosistem hizmetleri üzerinde sürdürülebilirliğe yönelik olumsuz bir etkinin oluşacağ1 düşünülmemektedir. Ayrıca çalışma alanında ulaşımdan kaynaklan kirlilik sorunlarının olmaması ve bununla beraber alanda ekolojik birimlerin ekosistem hizmeti üretme potansiyelini kısitlayacak endüstri kuruluşunun bulunmaması tarımsal ve termal turizm faaliyetlerini kısıtlayabilecek etkilerin minimum düzeylerde olacağının belirgin göstergeleri arasındadır. $\mathrm{Bu}$ durum seçilen çalışma alanı ile ilişkili olup, her alan için farklı sonuçlar elde edilebileceği unutulmamalıdır.

Elde edilen sonuçlara göre ekosistem hizmetleri dikkate alındığında kültürel turizm faaliyetlerinin uygunluğu konusunda fikir birliğine varılamamıştır. Bu da Haymana İlçesi'ndeki kültürel turizm faaliyetleri için ekosistem hizmetlerinin doğrudan bir etkisinin bulunmadığını göstermektedir.

Ekosistemhizmetleri kapsamında en uygun kırsal turizm türü olarak belirlenen termal turizmin, Haymana İlçesi'nde gerçekleştirilebilecek diğer turizm türleri ile desteklenmesi, turistlerin Haymana'da geçirdiği zamanı nitelikli hale getirerek, faaliyetlerin sürdürülebilirliğine katkı sağlayacak ve yakın çevredeki diğer kültürel ve doğal değerlerle de iliş ki kurulmasına yardımcı olacaktır. Ayrıca tek bir turizm türüne dayalı faaliyetlerin yer aldığ 1 alanlarda ekosistemler üzerindeki baskının giderek artacağ 1 , bunun da ekosistem hizmetlerinin sürdürülebilirliğine zarar vereceğinin unutulmamas1 gerekmektedir. 


\section{Teşekkür}

Bu makale, Prof. Dr. İlkden Tazebay danışmanlığındaE. Seda Arslan Muhacir tarafindan Ankara Üniversitesi Fen Bilimleri Enstitüsü'nde hazırlanan "Ekosistem Servisleri Kapsaminda Kirsal Turizm Alternatiflerinin Değerlendirilmesi: Ankara-Haymana İlçesi Örneği”’ başlıklı doktora tez çalışması esas alınarak hazırlanmıştır.

\section{Kaynaklar}

AKA, 2015. İstatistiklerle Ankara 2015. Ankara Kalkınma Ajans1, 240, Ankara.

Akpınar, N., 1995. Madencilik Sonras1 Alan Kullanım Alternatiflerinin Değerlendirilmesinde Fuzzy Set Tekniğinden Yararlanma Olanakları Üzerine Bir Araştırma. Ankara Üniversitesi Ziraat Fakültesi Yayınları, 38, Ankara.

Albayrak, İ., 2012. Ekosistem servislerine dayalı havza yönetim modelinin İstanbul- Ömerli havzası örneğinde uygulanabilirliği. Doktora Tezi, İstanbul Teknik Üniversitesi, Fen Bilimleri Enstitüsü, İstanbul.

Aleksieva, J., Stamov, St., 2005. Specialized Tourism Types. Rural tourism. Part II. Publishing, House Kota, Stara Zagora.

Anık, Z., 2007. Nesne yönelimli yazılım dillerinin analitik hiyerarşive analitik network prosesi ile karşılaştırılması ve değerlendirilmesi. Yüksek Lisans Tezi, Gazi Üniversitesi, Fen Bilimleri Enstitüsü, Ankara.

Barkauskas, V., Barkauskine, K., Jasinskas, E., 2015. Analysis of macro environmental factors influencing the development of rural touris m: Lithuanian case. Procedia - Social and Behavioral Sciences, 213: 167-172.

Boyd, J., Banzhaf, S., 2007. What are ecosystem services? They need for standardized environmental accounting units. Journal of Ecological Economics, 63: 616-626.

Costanza, R., Arge, R., De Groot, R., Farber, S., Grasso, M., Hanhon, B., Limburg, K., Naeem, S., O’Neill, R.V., Paruleo, J., Raskin, R.G., Sutton, P., 1997. The value of the world ecosystems ervices and natural capital. Nature, 387: 253-260.

Comino, E., Bottero, M., Pomarico, S., Rosso, M., 2014. Exploring the environmental value of ecosystem services for a riverbasin through a spatial multicriteria analysis. Land Use Policy, 36: 381-395.
Daily, G.C., Polasky, S., Goldstein, J., Kareiva, P.M., Mooney, H.A., Pejchar, L., Ricketts, T.H., Salzman, J., Shallenberger, R., 2009. Ecosystemservices in decision making: Time to deliver. Journal of Frontiers in Ecology and the Environment, 7:21-28.

De Groot, R.S., Alkemade, R., Braat, L., Hein, L., Willemen, L., 2010. Challenges in integrating the concept of ecosystem services and values in landscape planning, management and decision making. Ecological Complexity, 7(3): 260-272.

HB, 2016. Haymana Belediyesi Web Sitesi, Haymana, www.haymana.bel.tr, Erişim:25.04.2016.

Hermann, A., Schleifer, S., Wrbka, T., 2011. The concept of ecosystem services regarding landscape research: A review. Living Reviews in Landscape Research, 5:1.

Hernandez, J.M., Suarez-Vega, R., Santana-Jimenez, Y., 2016. The inter-relationship between rural and mass tourism: The case of Catalonia, Spain. Tourism Management, 54: 43-57.

Kubisewski, I., Costanza, R., 2012. Sürdürülebilir Refah İçin Ekosistem Hizmetleri. Worldwatch Enstitüsü Dünyanın Durumu 2012. Türkiye İş Bankası Kültür Yayınları, 303-312, İstanbul.

KTB, 2007.Türkiye Turizm Stratejisi 2023 Eylem Planı 2007-2013. T.C. Kültür ve Turizm Bakanlığ 1 Yayınları, Ankara.

Logsdon, R.A., 2011. Development of a quantification method for ecosystem services. Master thesis, Purdue University, Department of Engineering, India.

MEA, 2005. Ecosystems and Human Well-Being: Synthesis. Millennium Ecosystem Assessment. Island Press, Washington, DC.

Muhacir, E.S.A., 2014. Ekosistem servisleri kapsamında kırsal turizm alternatiflerinin değerlendirilmesi: AnkaraHaymana ilçesi örneği. Doktora Tezi, Ankara Üniversitesi, Fen Bilimleri Enstitüsü, Ankara.

Saaty, T.L., 1990. How to make a decision: The analytic hierarchy process. European Journal of Operational Research, 48: 9-26.

Soykan, F., 2003. Kırsal turizm ve Türkiye turizmi için önemi. Ege Coğrafya Dergisi, 12: 1-11.

Tezer, A., Çetin, N.İ., Onur, A.C., Menteșe, E.Y., Albayrak, İ., Cengiz, E.C., 2015. TR10/14/DFD/0039 No'lu Ömerli Havzası'nda Ekosistem Hizmetlerine Dayalı Bütünleşik Havza Yönetim Planının Geliştirilmesi Projesi araştırma raporu. 157 s., İstanbul. 